\title{
QUEEN'S
UNIVERSITY
BELFAST
}

\section{Introduction: Shakespeare and Riot}

Kate Flaherty, \& Lamb, E. (2018). Introduction: Shakespeare and Riot. Shakespeare, 14(3), 199-204. https://doi.org/10.1080/17450918.2018.1499672

\section{Published in: \\ Shakespeare}

\section{Document Version:}

Peer reviewed version

Queen's University Belfast - Research Portal:

Link to publication record in Queen's University Belfast Research Portal

\section{Publisher rights}

Copyright 2018 Taylor and Francis. This work is made available online in accordance with the publisher's policies. Please refer to any applicable terms of use of the publisher.

\section{General rights}

Copyright for the publications made accessible via the Queen's University Belfast Research Portal is retained by the author(s) and / or other copyright owners and it is a condition of accessing these publications that users recognise and abide by the legal requirements associated with these rights.

Take down policy

The Research Portal is Queen's institutional repository that provides access to Queen's research output. Every effort has been made to ensure that content in the Research Portal does not infringe any person's rights, or applicable UK laws. If you discover content in the Research Portal that you believe breaches copyright or violates any law, please contact openaccess@qub.ac.uk. 
Introduction

Shakespeare and Riot

By Dr Kate Flaherty (Australian National University) \& Dr Edel Lamb (Queen's University Belfast)

Corresponding author: Edel Lamb e.lamb@qub.ac.uk

Word count: 3785 


\title{
Introduction: Shakespeare and Riot
}

\begin{abstract}
This introduction establishes riot and riot studies as contexts for the analysis of Shakespearean drama and performance. It raises questions about the understanding and depiction of riot in early modern drama and about the provocation of riot in Shakespearean performance contexts to demonstrate how studies of Shakespeare and early modern drama might inform and be productively informed by fresh conceptualisations of riot.
\end{abstract}

Keywords: Early modern drama, theatre, performance, disorder.

We live, Alain Badiou claims, in "a time of riots" (5). Riot, as a term, a concept and an event, has a long and complex history, but it has entered renewed prominence in a global context following a series of high profile riots in the twentyfirst century (see Moran and Waddington 1). Consequently scholars from the disciplines of security studies, law, politics, sociology and education have begun to reconceptualise riot, evaluating the factors that influence the expression and interpretation of riot, investigating its internal logic and its political significance, and considering its transnational and transtemporal scope as a phenomenon (see Clover 18; Lewis et al.; Moran and Waddell 1-4; Sokhi-Bulley; Stott \& Reicher) Riot is a prevalent reality and it is being reimagined in scholarly and sociological thinking.

It is also being reimagined in twenty-first-century Shakespeare. The mob or riot scene of Julius Caesar, for instance, has acquired new urgency in productions (see Flaherty “Shakespeare plays” and Kirwan). In 2005 Deborah Warner's 
production at the Barbican installed tall glass riot barriers and used hundreds of extras to create a mob of fans pouring on to stage (see Chillington Rutter). More recently Robert Hastie's 2017 production for Sheffield Theatre staged rioters in hoodies invoking recent scenes of youth protest and riot (see Kirwan) and Nicholas Hytner's 2018 production for the Bridge Theatre involved some audience members as the mob (see Kesson). Riots have also found new prominence in twenty-first-century Shakespeare film. Geoffrey Wright's 2006 Macbeth features gang riots in contemporary Melbourne (Shohet 113) and Ralph Fiennes's 2011 Coriolanus depicts an aggressive mob being pushed back by riot police, an image that, as Philippa Sheppard points out, is "so common in modern news" (274). The riots of Shakespeare's drama are being reconceived in the context of familiar global media iconography of recent riots, gaining new significance in a period "marked by a series of high profile and heavily mediatized riots across the globe" (Moran and Waddington 1). This special issue explores connections between Shakespeare, his theatres and riot throughout history in this context of the global resurgence in riot and the burgeoning field of inquiry of riot studies. It raises questions about the understanding of riot in early modern drama and interrogates the depiction and provocation of riot in Shakespeare and his performance contexts to demonstrate how studies of Shakespeare and early modern drama might inform and be productively informed by fresh conceptualisations of riot.

Shakespeare and riot is not, of course, a new area of scholarship. Significant riots from the May Day riots of 1517 to the Midland Revolt of 1607 have been explored in detail in early modern studies alongside other acts of rebellion and insurrection and small scale riots by apprentices and others against enclosure, injustice, the price and distribution of food, for and against religious changes and 
against fiscal innovation (see Archer; Holstun; Walter; Wood). They have been scrutinized as acts of popular protest, mined as evidence of lower class ideals and the nature of authority, as disclosing much about crowd and communal activity in the period, and have been deemed a "negotiating strategy" (Archer 5) and a crucial element of "interaction between rulers and ruled" (Dunne 72). Shakespeare's depictions of mob violence have been examined in relation to these contexts. The representation of the "Ill-May-Day" riots in Sir Thomas More, for example, has been the subject of recent scholarly and media interest (Purkis 11). Coriolanus's urban "company of mutinous citizens" (1.1.s.d) armed to express their grievances about food shortages has been read in relation to early modern food riots (see Patterson 121152). Romeo and Juliet's opening "quarrel" (1.1.101) and "brawls" (1.1.86) and the "amorous riot" (Fitter 164) of the young lovers has been evaluated by Chris Fitter in relation to London's 1595 riots. The riots of the 1590s have also been noted as an informing context for the anti-enclosure riot references in As You Like It and for the depiction of urban riots and peasant rebellion in 2Henry VI (see Holstun 195-196). As this work has shown, Shakespeare's depictions of interaction, violence, riot and insurrection reveal much about modes of social control, rebellion and popular protest. Riot, it seems, was a feature of early modern urban and rural life and, as James Holstun notes, Shakespeare provides a "virtual encyclopedia of the various forms of riot and rebellion in early modern England" (195).

Yet, as Chris Fitter points out, the word riot is a "graphic misnomer" (159). The actions of those participating in what have subsequently been termed "riots" were often, though not always, different from our primary understanding of riot as a "violent disturbance" or "outbreak of violent civil disorder or lawlessness" (OED 4a). Food riots, for example, frequently took the form of "disciplined crowds" (Archer 6), 
and, as Andy Wood highlights, the organization of a meeting of more than twelve people to complain against enclosure, food prices or excessive rents was deemed riotous in the period and was addressed in mid-sixteenth-century legislation (36). The language of riot held diverse implications in the period and a range of terms were used to describe what we might now describe as riot. Shakespeare's plays, unsurprisingly, disclose this multiplicity. Acts of collective violent disturbance are represented in terms of riot in Sir Thomas More, in which they are described as "rough and riotous charge" (6.63) and part of the "discipline" of "riot" (6.126). Yet more commonly the actions of violent mobs are referred to in Shakespearean drama through the language of mutiny and rebellion (for example, Sir Thomas More 5.32; Coriolanus 1.1.141 and 1.1.149; Romeo and Juliet Prologue 3 and 1.5.79). The violent acts of the group of plebeians in Julius Caesar which result from Mark Antony's stirring of "hearts and minds to mutiny and rage" (3.2.123) share many features of the modern concept of riot in its combination of politicised impetus and crowd action against perceived tyranny or injustice combined with seemingly "senseless and unpredictable violence" (Gray and Sameley 9) but their actions are referred to as "mutiny" $(3.2 .206 ; 3.2 .225 ; 3.2 .226)$ rather than riot. ${ }^{1}$ The term "riot" is used to describe violent group action in King Lear $(1.4 .186 ; 2.2 .315)$ and individual disorder in The Merry Wives of Windsor (1.1.31). A violent act of civil disorder is then defined as a riot in legal terms in early modern culture and in Shakespearean drama, but this is not the principal meaning.

Instead "riot" often designated more generally any behaviour that was "wild" or "uncontrolled" (OED n. 1), and in Shakespeare's use of the term commonly relates to the indulgent and wasteful behavior, particularly of youth. The Merry Wives of Windsor's Fenton admits his "riots past, my wild societies" (3.4.8). The reckless 
youth of Prince Hal's behaviour is also described in terms of riot both by his detractors (1HenryIV 1.1.84; 2HenryIV 4.3.63; HenryV 1.1.57) and in the reformed King's accusations against his old companion, the "tutor and the feeder of my riots" (2HenryIV 5.5.62). Timon bemoans a youth of "general riot" (Timon of Athens 4.3.256) and the second senator describes Alcibades's young officer as a "rioter" (Timon of Athens 3.6.66) for his crime of "hot blood' (Timon of Athens 3.6.11). This unrestrained behavior, however, is not limited to the young but is used with similar implications of recklessness and indulgence when Antony's unrestrained behavior in Alexandria is described by Octavius as "rioting" (Antony and Cleopatra 2.2.76). In King John, as Ann Kaegi's essay points out, uncontrolled feeling is signaled through the language of riot (3.1.173). "Riotous" is employed across the corpus to designate a range of disorderly, passionate and uncontrollable emotions and behaviours from Laertes's "riotous head" (Hamlet 4.5.99) to Cleopatra's "riotous madness" (Antony and Cleopatra 1.3.29) to the court which has become "like a riotous inn" (1.4.222) in King Lear to the "riotous feeders" (2.2. 156) of Timon of Athens. In Shakespeare, then, the terminology of riot is primarily used to signal uncontrolled behavior and emotions.

Riot, in all of its definitions, has had a consistent association with theatre since Shakespeare's period. The potential for violent disorder to erupt was recognised early in the life of public theatre, and Shakespeare wrote his plays in a climate of strict regulation designed to contain the inflammatory potential of public gathering and public drama (see Bayer; Dunnum "Not to be altered"; Dutton;). It is not surprising that Shakespeare is prominent in Sean McEvoy's recent study, Theatrical Unrest: Ten Riots in the History of the Stage, 1601-2004, with four of the ten riots prompted by Shakespearean drama. Through imperial expansion, playhouses across the English- 
speaking world came to host Shakespeare's plays as their core repertoire and with them came vivid instances of riotous behavior. On 26 December 1833, the first licensed theatre in Sydney offered its first Shakespeare play: Colley Cibber's adaptation of Richard III. Loud objections about the casting from certain parts of the audience joined with rabble rousing in the pit to make the performance inaudible. One audience member intruded upon the stage, to be pushed by the actor playing Richard, John Meredith, onto the "spikes" that separated the stage from the pit. This story is one among hundreds documented by the colonial press in succeeding decades of riotous behaviour erupting in playhouses (Flaherty "Damn Him"). Public theatre had been banned in Australia until 1832 (Irvin 71), and the authorities' fears that allowing the populace of ex-convicts, soldiers, and newly arrived free-settlers to assemble in a make-shift public venue for entertainment would result in violence was realised in this incident.

Yet fears about disorder that influenced colonial legislation about public entertainment reflect what was by the nineteenth century a norm rather than a colonial exception. The longest running theatre riots took place over 67 nights in 1809 at London's Theatre Royal in Covent Garden. As Marc Baer has uncovered, the energy of these riots can be interpreted as politically conservative rather than radical (86-87). John Philip Kemble's entrepreneurial prerogative to fund his new theatre by raising ticket prices came up against the public's sense of ownership of a public institution. Macbeth was the play programmed for opening night, and thus Shakespearean performance was the originary site of this series of theatre riots known as the Old Price Riots. The shared imaginative capital of Macbeth to the theatrical warfare that ensued was exploited by Isaac Robert Cruikshank in many of his satirical etchings, including his 1809 depiction of Kemble as Macbeth asking 'Is this a rattle I see before 
me?' (Baer 64). This effective depiction of the public derision haunting Kemble as much as private guilt haunts Shakespeare's character is only one example of the ways in which the energies of Shakespearean drama are appropriated to instigate and disseminate the riotous energy of theatre.

If the material structure of the theatre was deemed public property, an even greater proprietorial fervour attended the repertoire. By the nineteenth century Shakespeare's plays were the key distinguishers between "legitimate" theatre and other popular entertainments and, as both Dobson and Bate have explored, a dynamic fulcrum for defining nation and authority. It is not surprising that in England Shakespeare's plays had a special intimacy with theatrical rioting. Heavily freighted by their own preoccupation with authority and subversion and by their accretions of cultural and political significance, they were destined to have catalytic force and to play many roles in instances of public disorder. Such impulses also found their most violent expression at the Astor Place riots in 1849 in New York when supporters of the home-grown celebrity, Edwin Forrest, chose the occasion of William Charles Macready's performance of Macbeth in the elite venue in Astor Place to foment violent protest against the English. Summoned by handbills that asked "Shall Americans or English rule in this city!" (Cliff 211), a crowd of thousands assembled outside the theatre. The regiments summoned to manage this crowd ultimately opened fire, killing more than thirty people (Cliff 225-228). Macready's diary reflects an effort to harness the terror of being under siege to power the embattled Macbeth's resistance, as he recalls "I flung my whole soul into every word I uttered exciting the audience to a sympathy even with the glowing words of fiction, while those dreadful deeds of real crime and outrage were roaring at intervals in our ears." (Cliff 225). At another performance of Macbeth by Macready's competitor Forrest in New York's 
Bowery Theatre, the play rung with a special, if different, significance, when the audience apparently responded to Forrest's delivery of "What rhubarb, senna, or what purgative drug, Would scour these English hence?" with a standing ovation and enthusiastic applause (Cliff xx). Shakespeare's drama and his status as cultural icon function in this most infamous Shakespearean riot as vehicle for and instigator of protest, heightened emotions and ultimately civil disorder and death.

Despite this evident fusion of the content of the play with the theatrical strife in which it becomes embroiled, relatively little scholarship has sought to map the relationship between Shakespeare as drama and riot. $^{2}$ More usually, theatre riots are understood as anomalous and isolated socio-political phenomenon and plays are seen as just plays. But why was Macbeth, a play which dramatises violent usurpation and revolt, at the centre of both the Old Price Riots and Astor Place Riots? Did Richard of Gloucester's tyranny equip John Meredith with a special prerogative of violence in patrolling the boundaries of the stage in Sydney in 1833? Such questions are factually unanswerable but offer a provocation to interrogate the accustomed distinction between theatrical imagination and "real life". The essays in this issue challenge the binary by exploring the complex implication of Shakespeare and early modern drama more broadly in instances of public disorder. The first two essays open up the definitional and historical complexities of early modern riot. In "Passionate Uprisings in Shakespeare's Lucrece”, Ann Kaegi situates Shakespearean riot within the context of the politics of affect. Reading Lucrece as one of several Shakespearean texts that demonstrate how passions such as grief might be used as a means of political protest and transformation, she explores the connections between two early modern concepts of riot: passionate riot and riot as civil revolt. This rereading of riot through the lens of recent work on emotions and affect unpacks the relationship 
between emotions and political turmoil, demonstrating the complex but also related concepts of riot in the period. In "“Cry Clubs for Prentices': (Not) Performing Riot in The Shoemaker's Holiday", Matt Williamson also disrupts conventional perceptions of early modern riot through his re-reading of Thomas Dekker's The Shoemaker's Holiday as an instance of dramatic response to riot. Exploring the dynamic connections between literature and history in his evaluation of apprenticeship, work, and an aborted riot, Williamson gestures towards a new history of early modern riot and its function in the drama of the period. Arguing for the different forms of riot in the early modern period, he resituates Dekker's play in the "unprecedented degree of highly politicised disorder" of the London riots of the 1590s to explore the significance of not performing riot in the theatre in 1599. These instances of literary depictions of riot in two examples by Shakespeare and his contemporary highlight the extent to which rethinking early modern riot, historical and literary, might challenge critical thinking on the disruptive behaviour of early modern culture.

The next two essays in this issue similarly challenge our perceptions of the history of Shakespeare and riot. As discussed, theatre holds a specific place in that history, from the riots directed at and situated within early modern playhouses to famous Shakespearean riots throughout theatre history. These essays explore two of Shakespeare's theatrical contexts. In "The Killing of John Lambe and the Subjectivity of the Crowd in the Early Modern Theatre", John Higgins turns to another nonShakespearean instance of riot in the early modern playhouse, the Fortune in 1628, to explore drama as material that may inspire riot as well as memorialise it and the significance of the early modern playhouse as a space for the expression of the emotions of the crowd and for the emergence of a collective political subject. While Williamson illustrates the importance of reading early modern drama as a response to 
riot, Higgins argues for drama as both a mode of interpreting early modern riot and as an instigator of riot. The potential of drama performed in a particular social, historical and theatrical context to provoke riot is also at the centre of Nicole Anae's essay, “Shakespearean Henry Kemble creates a 'row' on the Australian Colonial Stage, 1846-1859". Anae moves our consideration of riot across time and space to explore the ways in which theatre continues to function as a site of riot. She returns to Shakespeare to explore the playwright's role as a battleground for national and cultural capital in her reading of Henry Kemble's "monopolylogogues" on the nineteenth-century Australian stage. Raising questions about the writer and the play, the directors and performers, the audience and the space in instigating riot, these essays demonstrate the ways in which renewed attention to theatre riot can shed fresh light on early modern theatre, politics and the history of Shakespearean performance.

Together the work in this issue suggests that the relationship between Shakespeare and riot has more to reveal to us about the mechanics of early modern drama and theatre, public disorder, and the collective imagination than a set of uncanny coincidences. Early modern drama, with Shakespeare as a focal point, is not removed from historical protest, civil disorder and riot but has at particular junctures been demonstrably continuous with and constitutive of it. Theatre, and particularly Shakespeare, as a stimulus and site for riot is a disruptive and challenging concept; but it is one that emphasises the ongoing ability of drama and Shakespeare to challenge thinking and empower action. 
${ }^{1}$ On contemporary model of riot, see Moran and Waddington 15-38.

${ }^{2}$ Exceptions to this include Nigel Cliff's seminal study of the Astor Place riots, which firmly situates these riots within a 'Shakespearean Ark' (3); McEvoy; Gray and Sameley. Forthcoming work on the topic includes Dunnum, Performing the Audience.

Acknowledgements: We would like to thank Fiona Ritchie for her generous assistance with this special issue. The approach and ideas for this special issue have been shaped by our shared thinking and work on the topic. Thanks also to Gillian Russell, Derek Dunne and Patrick Gray.

\section{Works Cited}

Archer, Ian. The Pursuit of Stability: Social Relations in Elizabethan London. Cambridge: Cambridge UP, 2003. Print.

Badiou, Alain. The Rebirth of History: Times of Riots and Uprisings. Trans. Gregory Elliot. London: Verso, 2012. Print.

Baer, Marc. Theatre and Disorder in Georgian London. Oxford: Clarendon P, 1992. Print.

Bate, Jonathan. Shakespearean Constitutions: Politics, Theatre, Criticism, 1730-1830. Oxford: Clarendon P, 1989. Print. 
Bayer, Mark. Theatre, Community and Civic Engagement in Jacobean London. Iowa: U of Iowa P, 2011. Print.

Chillington Rutter, Carol. “Facing History, Facing Now: Deborah Warner's Julius Caesar at the Barbican Theatre.” Shakespeare Quarterly 57.1 (2006): 71-85. Print.

Cliff, Nigel. The Shakespeare Riots. New York: Random House, 2007. Print.

Clover, Joshua. Riot. Strike. Riot: The New Era of Uprisings. London: Verso, 2016. Print.

Dobson, Michael. The Making of a National Poet: Shakespeare, Adaptation and Authorship, 1660-1769. Oxford: Clarendon P, 1992. Print.

Dunne, Derek. Shakespeare, Revenge Tragedy and Early Modern Law: Vindictive Justice. Basingstoke: Palgrave Macmillan, 2016. Print.

Dunnum, Eric. “'Not to Be Altered': Performance's Efficacy and Audience Reaction in The Roman Actor." Comparative Drama 46.4 (2012): 517-543. Print.

Dunnum, Eric. Performing the Audience: Controlling the Unruly Playgoer in Early Modern London. London: Routledge, forthcoming. Print.

Dutton, Richard. Mastering the Revels: The Regulation and Censorship of English Renaissance Drama. Iowa: U of Iowa P, 1970. Print.

Fitter, Chris. "'The quarrel is between our masters and us their men': Romeo and Juliet, Dearth and the London Riots.” English Literary Renaissance 30 (2000): 154-183. Print.

Flaherty, Kate. "Shakespeare Plays and Civic Strife: The Julius Caesar Fiasco is Nothing New.” The Guardian 16 Jun. 217: n.p. Web. 21 May 2018. 
Flaherty, Kate. "'Damn him and the spikes': Richard III, Riot, and the Formation of an Australian Colonial Theatre Public.” Cogent Arts \& Humanities 3.1 (2016): n. p. Web. 21 May 2018.

Gray, Patrick, and Maurice Sameley. "Shakespeare and Henri Lefebvre's 'Right to the City': Subjective Alienation and Mob Violence in Coriolanus, Julius Caesar, and 2 HenryVI.” Textual Practice (2017): 1-26. Web. 21 May 2018.

Holstun, James. "Damned Commotion: Riot and Rebellion in Shakespeare's Histories.” A Companion to Shakespeare's Works, Volume II. Ed. Richard Dutton and Jean Howard. Oxford: Blackwell, 2003. 194-219. Print.

Irvin, E. Theatre comes to Australia. St. Lucia: U of Queensland P, 1971. Print. Kesson, Andy. "II do fear the people': Theatre and the Problem with Audiences." Before Shakespeare 16 Feb. 2018: n. p. Web. 21 May 2018.

Kirwan, Peter. “Julius Caesar (Sheffield Theatres) @ The Crucible.” The Bardathon 1 Jun. 2017: n. p. Web. 21 May 2018.

Lewis, P., T. Newburn, M. Taylor, C. McGillivray, A. Greenhill, H. Frayman and R. Proctor. Reading the Riots: Investigating England's Summer of Disorder. London: The London School of Economics and Political Science and The Guardian, 2011. Web. 21 May 2018.

McEvoy, Sean. Theatrical Unrest: Ten Riots in the History of the Stage, 1601-2004. London: Routledge, 2016. Print.

Moran, Matthew, and David Waddington. Riots. Basingstoke: Palgrave Macmillan, 2016. Print.

Patterson, Annabel. Shakespeare and the Popular Voice. Oxford: Blackwell, 1989. Print. 
Purkis, James. "Shakespearean Hospitalities in Sir Thomas More." Cahiers

Élisabéthains: A Journal of English Renaissance Studies 89.1 (2016): 9-26. Print.

Sheppard, Philippa. Devouring Time: Nostalgia in Contemporary Shakespearean Screen Adaptations. Montreal: McGill-Queen's P, 2017. Print.

Shohet, Lauren. "Macbeth: The State of the Art." Macbeth: A Critical Reader. Ed. John Drakakis and Dale Townshend. London: Bloomsbury, 2013. 95-122. Print.

Sokhi-Bulley, Bal. "Re-reading the Riots: Counter-conduct in London 2011." Global Society 30.2 (2016): 320-339. Print.

Stott, Cliff, and Steve Reicher. Mad Mobs and Englishmen: Myths and Realities of the 2011 Riots. London: Robinson, 2011. Print.

Walter, John. Crowds and Popular Politics in Early Modern England. Manchester: Manchester UP, 2007. Print.

Wood, Andy. Riot, Rebellion and Popular Politics in Early Modern England. Basingstoke: Palgrave Macmillan, 2002. Print. 